(1) 地球環境と経済成長：エネルギー消費の動学的最適化に 関するモデル論的考察

ON THE OPTIMAL INTERTEMPORAL ALLOCATION OF ENERGY WITH A VIEW TO ACHIEVE LONG-TERM ECONOMIC AND ENVIRONMENTAL SUSTAINABILITY

\author{
井 村 秀 文* \\ Hidefumi IMURA*
}

\begin{abstract}
Energy and environmental issues are crucially interrelated. There are two concurrent problems which may determine the future of the human society; depletion of the resources such as oil, and environmental damages associated with the resource use. Resources once utilized are ultimately transformed to differerent forms of wastes whereas some of them are accumulated in air and water, causing persistent damages to the global environment. A typical example is the possible climatic change due mainly to $\mathrm{CO} 2$ from fossil fuels. This raises a fundamental question about the long-term management of exhaustible resources and the wastes generated by their use. From a planner's standpoint, this is an intertemporal optimization excersize that takes into account both the resource and environmental constraints. This paper presents a general model suitable for this arguement. The utilitarian optimum theory developed by Dasgupta and Heal is generalized by introducing the damage function of the waste accumulated in the environment. Numerical analysis is made to examine the typical solution for the Cobb-Douglas production function. Policy implication of the optimal development paths is discussed based on this model calculation.
\end{abstract}

KEY WORDS; optimal development, global environment, environmental economics, non-renewable resources, environmental risks

1.はじめに

マルサスの「人口論」以来約 200 年、ローマクラブの「成長の限界」報告書から丁度 20 年を迎えた。世界人 口の幾何級数的な增大の前に、「資源」と「地球環境」に関する有限性がますます現実のものとなっている。 環境と経済の将来を左右する鍵はエネルギーである。1970年代、石油危機に触発されて、枯渴性資源(exhaustible natural resource)の問題がようやく正面から取り上げられるようになった。しかし、まだ、ネルギーをは じめとする資源の有限性が人類社会の発展に対する絶対的な制約になるかもしれないとの危機感は薄い。

「成長の限界」報告書は、経済学者の間で必ずしも好評ではなかったと言われる。「市場の原理」と「人類 の嵭知二科学技術」を信奉する立場に立てば、代替資源の開発・利用、新技術の発明・発見によって問題は克 服され、資源の枯渴が成長の絶対的制約となるような事態は想定されない。しかし、将来もそのような楽観論 が成り立つであろうか。「持続可能な成長」が唱えられてはいるが、21世紀の人類社会が如何なる技術原理と 政治・経済・社会秩序の上にそれを達成するのかの解答は与えられていない。市場メカニズム（見えざる手） による調整を信頼していれば地球環境は救えるであろうか。現在実現している価格体系の下での経済合理的な 行動が、地球環境保全にとって果して合理的かつ最適であろうか。地球環境の破壊は急速に進行しており、地

* 九州大学工学部環境システム工学研究センター、Institute of Environmental Systems, Faculty of Engineering, Kyushu University 
球規模で一度破壊された生態系のバランスはほとんど復元不能である。市場の力を過信していて、後で取り返 しのつかない事態をもたらす恐れはないだろうか。

市場に問題解決の全てを委ねることが出来ないとすれば、将来にわたる資源消費、経済成長、地球環境の相 互連関を予测・評価し、何らかの価值基準に基づく規範的視点から、地球環境と人類にとって最適な政策を決 定し、計画的にこれを実施する必要がある。もちろん、計画経済の失敗に見るとおり、人知もまた万能ではな い。長期的な地球環境管理の最善の方法は、市場と計画の併用ではなかろうか。ここに、市場の失敗を是正・ 防止するための規範として、地球環境資源を最適に管理するための計画を理論的に検討することの意味があ る。本論では、こうした問題認識に立って、地球環境資源管理のための1つの规範的方法論を提示し、再生不 可能な資源（エネルギー）と地球環境及び経済成長の関係をモデル論的に考察してみたい。

\section{2 。資源と経済成長、環境}

枯渴性資源と経済成長の関係を動学的視点からモデ化したのがDasgupta and Heal [1,2]である。彼らによ れば、最適な資源利用経路は、現在から将来（ここでは第T期までとする）にわたる消費の効用U(C) 価值の棇和を、資源制約条件の下で最大化することである。第 $\mathrm{t}$ 期における資源利用量を $\mathrm{X}_{\mathrm{t}}$ 、資本ストック を $\mathrm{K}_{\mathrm{t}}$ 、投資を $\mathrm{I}_{\mathrm{t}}$ 、生産を $\mathrm{Y}_{\mathrm{t}}$ 、消費を $\mathrm{C}_{\mathrm{t}}$ と置けば、最適成長経路問題は次式で記述される。 $\mathrm{F}(\mathrm{X}, \mathrm{K})$ は生産関 数、 $\rho$ は時間の割引率である。

$$
\begin{gathered}
\operatorname{Max} W=\sum_{t=0}^{T} \frac{1}{(1+\rho)^{t}} U\left(C_{t}\right) \\
\text { s.t. } \quad \sum_{t=0}^{T} X_{t} \leq S_{0} \\
K_{t+1}=K_{t}+I_{t} \\
Y_{t}=F\left(X_{t}, K_{t}\right)=C_{t}+I_{t}
\end{gathered}
$$

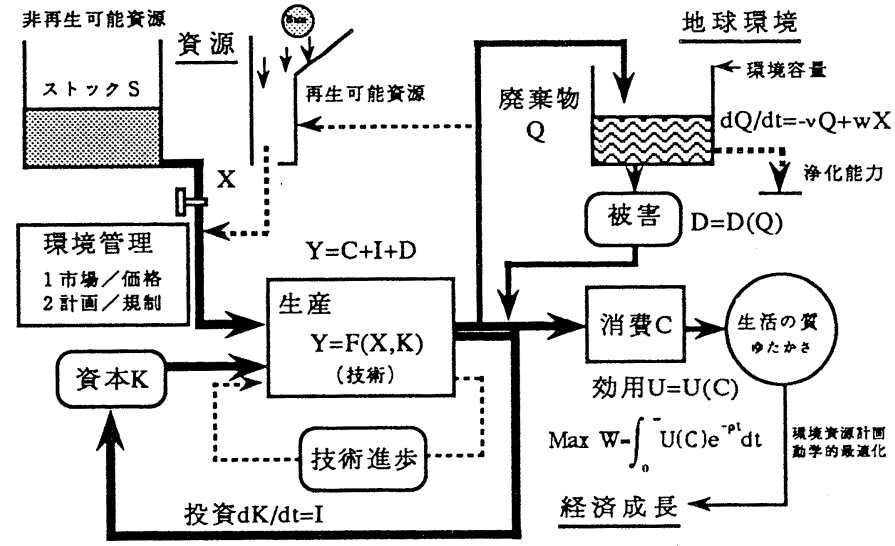

図 1 持続可能な成長：動学的地球環境資源管理の体系

政府（計画者）は、Wの最大化を1つの政策目標として、これを達成するための最適解に従って、毎年の資 源利用量Xと消費Cを計画的にコントロールする。

Dasgupta達 は、Cobb-Douglas型生産関数を中心に、上記問題の解の特性を詳細に検討している。しかし、 彼らのモデルには、環境問題、すなわち、資源消費によって生成される廃棄物（污染物質）及びその蓄積が地 球環境に及はす影響は全く考虑されていない。本論文では、資源、生産、環境の相互連関を図 1 のよににモデ ル化し、資源と環境の 2 つ制約を考剫するようにDasgupta達の議論を一般化する。

環境中に廃裹物（たとえば、CO2等の温室効果ガス）が蓄積されるに従い、地球生態系は非可逆的な変化を うけ、さまざまな形で人類社会に被害をもたらす[3]。地球の環境容量、たとえば地球の平均気温について何C までの上昇が許容されるかを評価することは極めて難しいが、ここでは経済成長にマイナスの影響がもたらさ れ、社会的に許容できなくなる限界を環境容量と考える。このため、廃棄物ストックQを変数とする被害関数 $\mathrm{D}_{\mathrm{t}}=\mathrm{D}\left(\mathrm{Q}_{\mathrm{b}}\right)$ を仮定する。実際の環境被害は、現在の環境状態が実現するまでの履歴に左右されるが、ここでは 簡単のため、その時点における廃钭物の量だけによって決まるとする。

環境への被害の発生は、その分だけ本来消費及び投資に振り向けられるはずの財が利用できなくなることを 意味する。すなわち、式(4)の代わりに次式となる。 
一般に環境中に蓄積された廃裹物は、化学的分解、物理的稀釈などのメカニズムによって、時間をかければ ある程度自然に净化される。CO2についてみれば、海洋が大きな吸収能力を有している（ただし、その吸収 限界は明らかではない）。そこで、環境中廃裹物の蓄積を次式で記述する：

$$
\mathrm{Q}_{t}=(1-v) \mathrm{Q}_{t-1}+\mathrm{w} \mathrm{X}_{\mathrm{t}-1}
$$

ここで、レは廃棄物の净化速度、wは資源 1 単位の消費によって環境中に排出される廃衰物の量である。

この最適化問題は、ラグランジアン

$$
\begin{aligned}
& L=\sum_{t=0}^{T}(1+\rho)^{-t} U\left(C_{t}\right)+\sum_{t=0}^{T} \xi_{t}\left[F\left(X_{t}, K_{t}\right)-C_{t}-I_{t}-D\left(Q_{t}\right)\right] \\
& \quad+\sum_{t=0}^{T-1} \phi_{t}\left(K_{t}+I_{t}-K_{t+1}\right)+\sum_{t=0}^{T-1} \zeta_{t}\left[(1-v) Q_{t}+w X_{t}-Q_{t-1}\right]+\lambda\left(S_{0}-\sum_{t=0}^{T} X_{t}\right)
\end{aligned}
$$

を用いて定式化できる。 $\xi_{\mathrm{t}}, \phi_{\mathrm{t}}, \zeta \mathrm{\jmath}, \lambda$ はラグランジュの未定乗数である。その結果は次式となる。

$$
\begin{array}{lll}
\frac{\partial L}{\partial C_{\mathrm{t}}}=0: & (1+\rho)^{-t} \mathrm{U}^{\prime}\left(\mathrm{C}_{\mathrm{t}}\right)=\xi_{\mathrm{t}}, & \mathrm{U}^{\prime}\left(\mathrm{C}_{\mathrm{t}}\right)=\xi_{\mathrm{t}}^{*} \\
\frac{\partial L}{\partial \mathrm{X}_{\mathrm{t}}}=0: & \xi_{\mathrm{t}} \frac{\partial \mathrm{F}}{\partial \mathrm{X}_{\mathrm{t}}}+\mathrm{w} \zeta_{\mathrm{t}}=\lambda, & \xi_{\mathrm{t}}^{*} \frac{\partial \mathrm{F}}{\partial \mathrm{X}_{\mathrm{t}}}+\mathrm{w} \zeta_{\mathrm{t}}^{*}=\lambda^{*} \\
\frac{\partial L}{\partial \mathrm{K}_{\mathrm{t}}}=0: & \xi_{\mathrm{t}} \frac{\partial \mathrm{F}}{\partial \mathrm{K}_{\mathrm{t}}}+\xi_{\mathrm{t}-1}-\xi_{\mathrm{t}}=0, & \xi_{\mathrm{t}}^{*} \frac{\partial \mathrm{F}}{\partial \mathrm{K}_{\mathrm{t}}}+\xi_{\mathrm{t}-1}^{*}-(1+\rho) \xi_{\mathrm{t}}^{*}=0 \\
\frac{\partial L}{\partial \mathrm{Q}_{\mathrm{t}}}=0: & (1-v) \zeta_{\mathrm{t}}-\zeta_{\mathrm{t}-1}=\xi_{\mathrm{t}} \mathrm{D}^{\prime}\left(\mathrm{Q}_{\mathrm{t}}\right), & (1-v) \zeta_{\mathrm{t}}^{*}-(1+\rho) \zeta_{\mathrm{t}-1}^{*}=\xi_{\mathrm{t}}^{*} \mathrm{D}^{\prime}\left(\mathrm{Q}_{\mathrm{t}}\right) \\
\frac{\partial L}{\partial \mathrm{I}_{\mathrm{t}}}=0: & \xi_{\mathrm{t}}=\phi_{\mathrm{t}} &
\end{array}
$$

たたし、

$$
\xi_{t}^{*}=(1+\rho)^{t} \xi_{t}, \quad \zeta_{t}^{*}=(1+\rho)^{t} \zeta_{t}, \quad \lambda_{t}^{*}=(1+\rho)^{t} \lambda
$$

と置いた。式(8)は、第 $\mathrm{t}$ 期における消費の限界効用の現在価值が

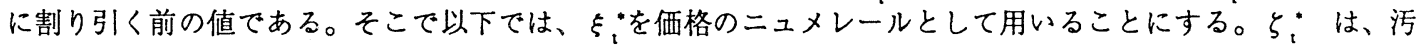
染物質 1 単位の価值（シャドウプライス）と解釈され、式(9) は、資源 1 単位を限界的に消費することによる 生産と、その際に発生する污染物質の価值（污染被害）の和が資源価格（シャドウプライス）入*に等しいこ とを意味する。

初期条件として、 $\mathrm{X}_{0}, \mathrm{~K}_{0}, \mathrm{C}_{0}, \xi_{0}=\mathrm{U}\left(\mathrm{C}_{0}\right), \lambda=\xi_{0} \partial \mathrm{F} / \partial \mathrm{X}_{0}$ の各值を与えれば、式(5)、(6)、(8), (9), (10), (11)の組によって、最適解が与えられる。

\section{3。最適解の特性}

上で導いた差分方程式の解の特性を一般的に論じるのは難しいので、ここでは、Cobb-Douglas型生産関数：

及び、Felici型効用関数：

$$
F(X, K)=X^{a} K^{b} L^{c} \quad(a+b+c=1)
$$

$$
U(C)=\frac{1}{1-\eta} C^{1-\eta}(\text { for } \eta>1) \text { or } \quad U(C)=\log C(\text { for } \eta=1) ; \quad U(C)=C^{-\eta}
$$

について検討する。たたし、以下では労働 L は一定とする。 
本モデルにおいては、環境の制約は被害関数を通じて取り入れられるが、現実に被害関数を設定することは 極めて難しい。計画論的な視点に立つとき、ここで問題とする被害は現実に生起した被害ではなく、将来につ いて（ある仮定の下で）予測ないしは懸念される被害のリスクである。それは、環境の価值や環境変化によっ て社会が被る影響を計画者がどう認識・評価するかに依存する。計画者が環境を重視するほど、リスクを大き めに評価するような被害関数を設定するであろう。ここでは、污染蓄積量がある量 $\mathrm{Q}_{0}$ を超えたときにリスク が増大するような関数を仮定する。

$$
D(Q)=D_{0}\left(1-Q / Q_{0}\right)^{d} \quad\left(\text { for } Q \geq Q_{0} ; d>0\right)
$$

このモデルのシミュレーション結果を次に要約する。なお、理論的視点からは $\mathrm{T} \rightarrow \infty$ として論ずべきである が、地球温暖化などの具体的問題を考察する立場からはむしろ Tは充分大きなある有限な值としておく方が現 実的である。本論では $\mathrm{T}=100$ 年にとる。 $\mathrm{T} \rightarrow \infty に つ$ いて解が得られるためには、生産関数、被害関数に ついて各種の数学的制約が課されるが、Tを有限と する場合には、これらの制約からも自由となる。

Cobb-Douglas生産関数の係数の值については、米 国経済について $\mathrm{a}=0.64, \mathrm{~b}=0.26, \mathrm{c}=0.10$; 西独につい て、1960年から1981年の間に、aの值は $0.14 か ら 0.55$ に上昇、逆にbの值は 0.86 から 0.33 に減少との報告が ある（c=0.1でほは一定）[4]。計算にあたっては、 この数字を参考にパラメータを設定した。

(1)まず、環境への影響が全くないとき（ $\mathrm{D}_{0}=0 ） に$ は、Dasgupta達が既に導いたと同じ結論が得られ る。最適資源利用経路は割引率 $\rho$ に依存する。 $\rho$ が 大なほど、将来よりも現在の消費が選択され、逆に $\rho$ が小の場合には将来の消費が大きめになる。 $\rho=$ 0 の場合、消費は上昇し続ける（図2.1）。 $\rho$ 小 の場合、消費が過大となり、投資不足の結果、生産 は滅少し、やがて資本を食い潰す事態となる（図2 の $\rho=0$ のケース）。 $\rho$ 大の場合、将来は消費より も投資に重点が置かれるため生産は增大するが、将 来世代の消費は儀牲を受ける（図 $2 \rho=0.05$ のケー ス）。以下では、 $\rho=0.02$ を採用するが、これは 1 世代（約30年）後の価值を約半分に割引くことに相 当する。

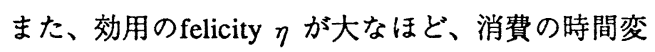
化は小さく、消費水準は時間によらず一定となる。

（2）出発時点での消費水準 $\mathrm{C}_{0}$ を所与として、資源利 用量 $\mathrm{S}_{0}$ を増大させた場合に消費の経路がどう変化す るかを見たのが図3である。 $\mathrm{S}_{0}$ が大なほど消費水华 は上昇するが、同じC から出発する限り変化は極め て小さい。しかし、利用可能な資源量が小さい場合 には資源の枯渇と資本の消滅が生じる。この事態を 避けるには消費水洀を下げねばならない（初期値 $\mathrm{C}_{0}$ をもっと小にとる）。逆に、利用可能資源量が大き い場合、消費を低く抑えることは過剩な資本蓄積を もたらすだけであり、消費者主権的には必ずしも望 ましい事態ではない。消費水準をもっと上昇させて

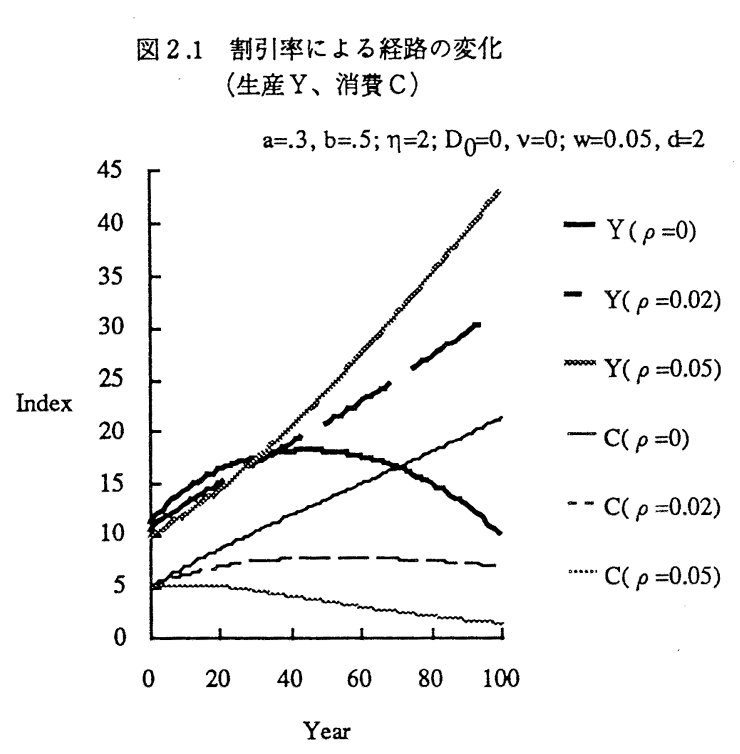

図2.2 割引率による経路の变化 （資源利用量 $\mathrm{X}$ 、資本 $\mathrm{K}$ )

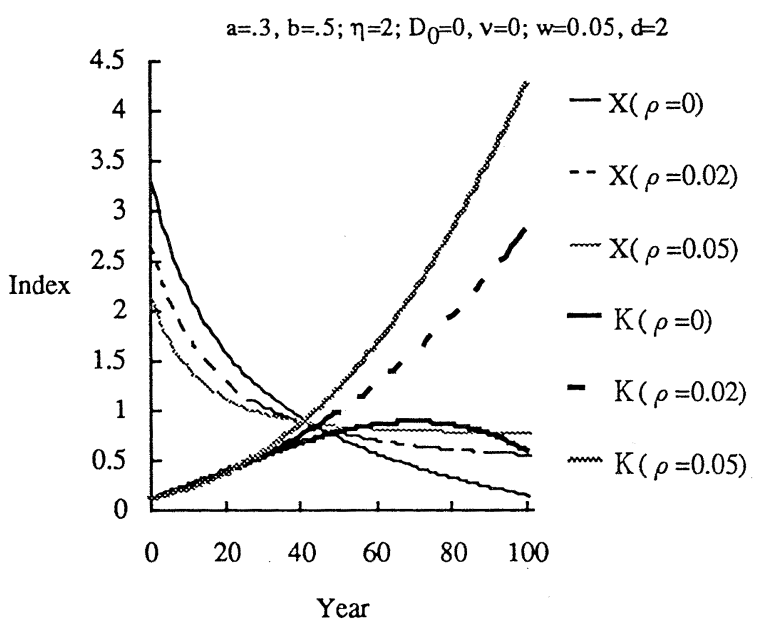


も成長は持続し得るからである（ $\mathrm{C}_{0}$ 大から出発し てもよい）。利用可能な資源量が少ない場合、現 在の資源利用を抑制した結果、将来の成長に必要 な充分な投資が行われなくなる恐れがある。その ような事態は、現実に多くの発展途上国において 見られる。環境と経済成長の調和が求められる由 縁である。

（3）環境への影響を考慮に入れた場合には、污染 物質量とリスクの大きさ（パラメータ $\mathrm{D}_{0}, \mathrm{~d}$ ), 環境 の净化能力 $(\nu)$ が経路に影響を及はす。

環境被害なしの場合の最適経路の一例を図4.1に 示す。資源利用量は単調隇少である。これに対し て、環境被害を考慮したのが図4.2である。計画期 間の早い時期で資源利用を抑制して、計画期間の 終り近くで再び資源利用を増加させることにな る。これは、一度発生した污染の影響が持続的で あることと、時間の割引によって遠い将来の被害 の現在価值は低く評価されるためである。この結 果、計画中期に一時縮小した生産は再び増加する。 いわば、環境被害を淩ぐ生産を上げることによって 効率を追及する形である。

污染被害がもっと大きい場合、例えば污染が完全 に蓄積的（ $\nu=0)$ なときには、ほほ同じ消費水準を 維持すれば、投資は堿少し、やがて資本の枯渴を招 来する（図4.3）。このような破局を避けるために は、消費水準を低下させねばならない（図4.4）。

利用可能資源量が大量の場合には、計画後期に資 源利用を増大させる傾向はさらに顕著になる（図 4.5)。

（4）図4.2に対応する資源及び污染のシャドウプラ イス $(\lambda, w \zeta)$ 、消費の限界効用価值 $(\xi)$ を計算し

図4.2最適経路：環境被害あり

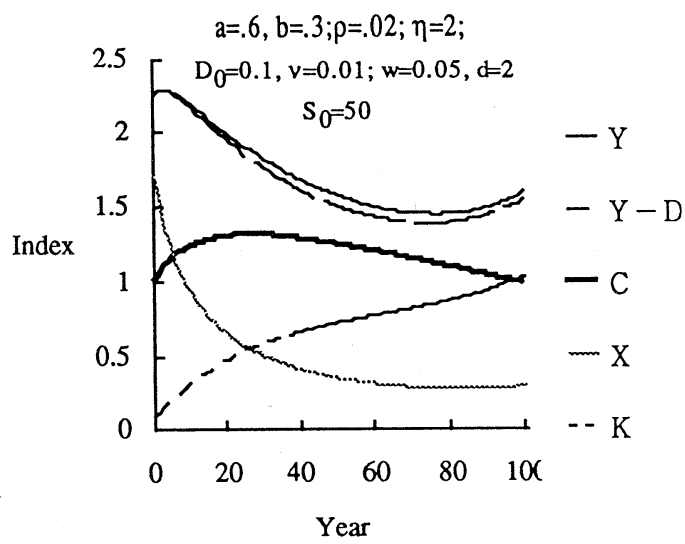

図3 資源利用量と消費

$a=.6, b=.3 ; p=.02 ; \eta=2 ; D_{0}=0, v=0 ; w=0.05, d=2$

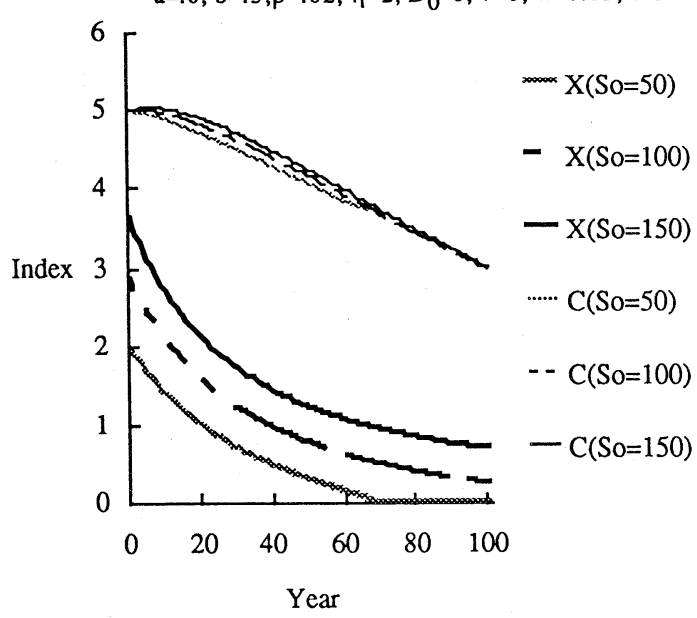

図4.1 最適経路：環境被害なし

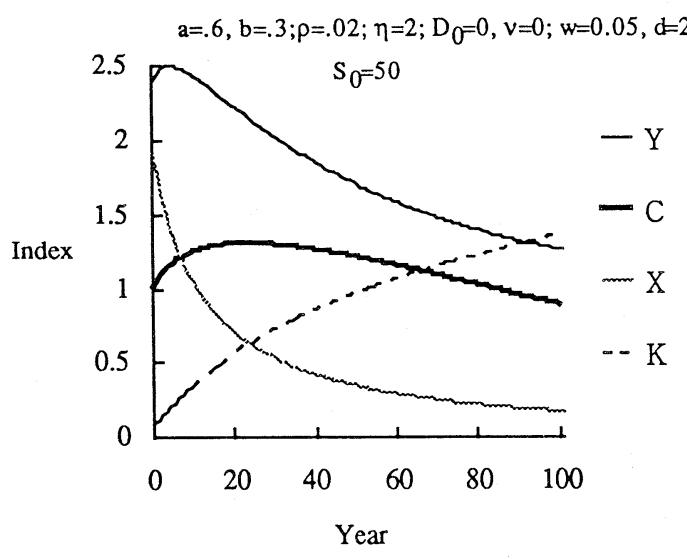

図4.3 最適経路：環境被害增大の場合

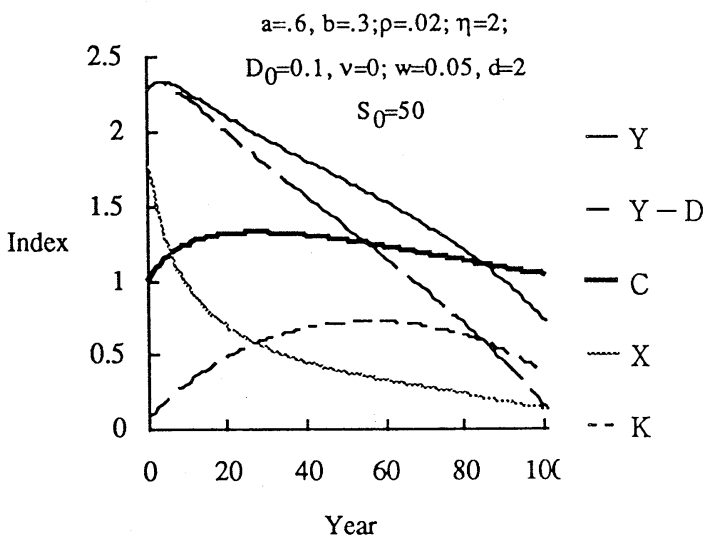




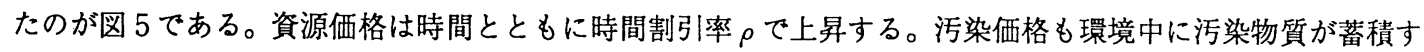
るにつれて上昇する。生産に対する被害の比率は $3 \%$ 程度と小さいが、資源価格に占める環境被害コストの比 率は40\%程度にもなり得ることがこの例から示される。 巾が小であればその変化も小さい。

図4.4 最適経路：環境被害増大により消費水 準低下の場合 $\mathrm{a}=.6, \mathrm{~b}=.3 ; \rho=.02 ; \eta=2$;

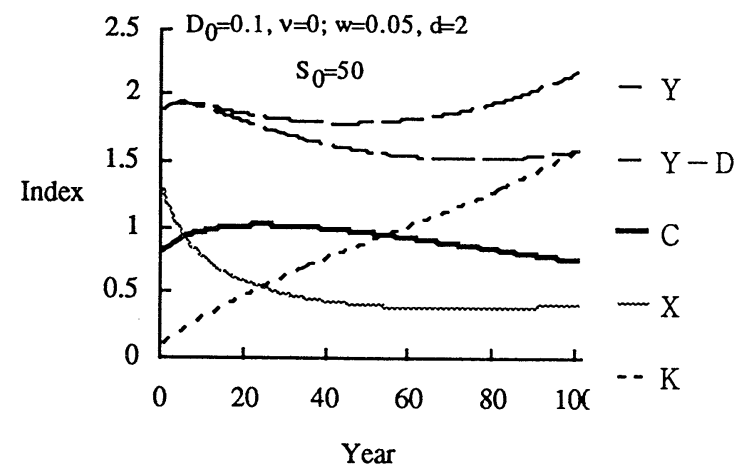

図4.5 最適経路：環境被害あり、資源利用量 增大の場合

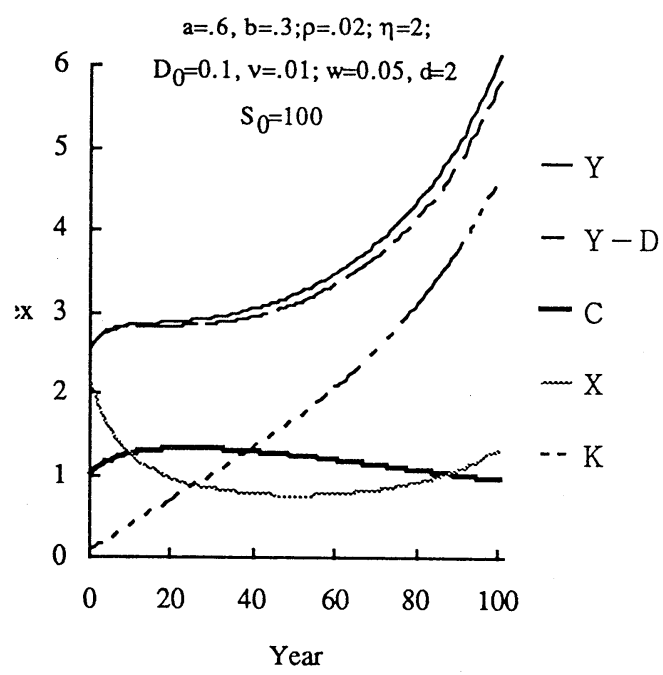

4. 政策的意味：動学的環境計画

本論で提案したモデルは、環境影響をも考虑しつつ有 限な資源を計画的に管理するための 1 つの规範的考え方 であり、地球的規模での長期的な環境管理についてのヒ ントを与えるものである。ただし、数学的な解が社会に とって必ずし現実的とは限らない。長期的な環境資源管 Index 理の政策的ガイドラインとして、本モデルから示唆され ることを列挙してみよう。

(1) 消費主義政策：消費の効用和Wを最大化する政策は、 それだけを唯一の規範とする場合には、持続的発展に反 する政策を提案する恐れがある。特に、計画期間が有限 である場合、計画期間以降の将来を無視した政策が最適 とされかねない。

（2）成長主義政策：GN P で代表される生産をとにかく増 大させる政策と消費主義の政策はしばしば矛盾する。成 長主義は消費を儀牲にし、一方、消費主義の政策は資本

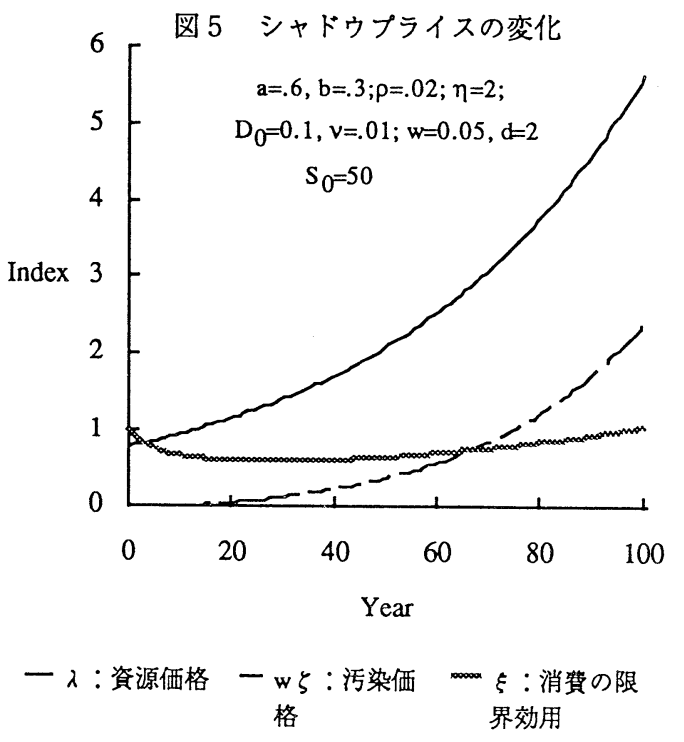
ストックを喰い潰してしまう恐れがある。

（3）持続主義政策：将来における資源の枯渴を見越して資本の蓄積を図る。同時に成長持続のための投資を損 なわない範囲で消費水準を上げる。このバランスの舵取が現実の経済運営の問題である。

（4）資源枯渴の回避：資源枯渴の事態そのものが望ましくないとする考え方である。熱帯の森林保護などがこ れである。資源保全を前提とする別の政策規範が必要である。

（5）環境被害と資源の時間配分：環境被害がない場合に早い時期ほど多くの資源を消費することになるが、環 境被害を考える場合には、初めのうちは資源の利用を抑制した方がよい。しかし、これはあくまでも将来にわ たる消費の効用和の最大化という目標設定からの帰結である。目標そのものの妥当性から議論が必要である。 
（6）環境被害の回避：経済的効率尺度からは、環境被害を発生させてもそれを上回る生産を達成すればよいと いう論法も成り立ち得る。高度経済成長期の公害問題がこれである。地球温暖化のような被害評価の難しい問 題をめぐって、これは議論の必要な課題である。

(7) 現在と将来：時間割引率の問題である。割引率を大きく設定することは将来世代の幸福を低く評価するこ とであり望ましくない。しかし、割引率をあまり低く設定することは、過剩な消費につながる。

(8) 計画期間：計画のタイムスパンによって、最適経路は変化する。蓄積性の環境污染を考慮する場合、これ は重要となる。100年もの長期的将来を考慮にいれたとしても、それよりさらに先の人類社会の将来について の配㢜が必要である。

(9)被害関数：環境に対して子予測される被害ないしはリスクの設定において、既に計画者の思想が反映される。客観 的に評価可能なリスクと計画者の主観的リスクの両者が問題である。

\section{5 . 再生可能資源への転換と持続的成長}

エネルギー源として化石燃料に依拠する限り、やがて必ず資源は枯渴し、生産は減少する。この事態を避けるに は、バックストップテクノロジー（BT：太陽エネルギー等の再生可能エネルギーや核融合なとの、人類にとって究 極的なエネルギー技術) への開発投資と転換が必要である。これには、研究開発、実験ブラント建設、実用プラント 建設などの費用が含まれる。再生可能エネルギー開発への投資を J、現在までの累積投資を $\mathrm{M}_{\mathrm{t}}$ とおけば、利 用可能な再生可能エネルギーの量及び生産次式となる：

$$
\begin{array}{r}
\mathrm{R}_{\mathrm{t}}=\Psi\left(\mathrm{M}_{\mathrm{t}}\right), \quad \mathrm{M}_{\mathrm{t}+1}=\mathrm{M}_{\mathrm{t}}+\mathrm{J}_{\mathrm{t}} \\
\mathrm{Y}_{\mathrm{t}}=\mathrm{F}\left(\mathrm{Z}_{\mathrm{t}}, \mathrm{K}_{\mathrm{t}}\right)=\mathrm{C}_{\mathrm{t}}+\mathrm{I}_{\mathrm{t}}+\mathrm{J}_{\mathrm{t}}+\mathrm{D}_{\mathrm{t}}, \quad \mathrm{Z}_{\mathrm{t}}=\mathrm{X}_{\mathrm{t}}+\mathrm{R}_{\mathrm{t}}
\end{array}
$$

技術開発に関する過去の样々な経験によれば、関数せはロジスティック型曲線で近似される。すなわち、累積投 資が少ないあいた、資源開発の速度は遅いが、累積投資がある程度大きくなれば資源開発は急速に進む。しかし、再 生可能資源と言えども地球上で利用可能な量には上限があるから、やがて開発は限界に達する。バックストップテク ノロジーへの移行を想定する場合の最適経路は、新たに次の式を加えることによって与えられる。

$$
\gamma_{\mathrm{t}}^{*}=\xi_{\mathrm{t}}^{*} \frac{\partial \mathrm{F}}{\partial \mathrm{Z}_{\mathrm{t}}} \quad(17.1), \quad \gamma_{\mathrm{t}}^{*} \mathrm{R}^{\prime}\left(\mathrm{M}_{\mathrm{t}}\right)=\xi_{\mathrm{t}}^{*} \frac{\partial \mathrm{F}}{\partial \mathrm{K}_{\mathrm{t}}} \quad(17.2), \quad \mathrm{w}_{\mathrm{t}}^{*}+\gamma_{\mathrm{t}}^{*}=\lambda_{\mathrm{t}}^{*}
$$

ここで、 $\gamma_{\text {: }}^{*}$ は、B T が存在するときの資源の価格である。式(17.1)と(17.2)は、B Tへの開発投資の限界生産性と資 本の限界生産性が等しいことを表わす。

\section{6。おわりに}

地球環境の複雑な現象を前にして、専門家ですら確実に予測し得ない数々の問題があり、ましてや一般市民 が保有する情報は限られている。不確実性のともなう長期的なりスクよりも短期的で確実な利益の方が重視さ れ、大きな被害が現実に発生するまで何の対策も取られない恐れがある。地球環境保全のために市場メカニズ ムを利用することは必要不可欠であるが、市場に全てを委ねることも出来ない。地球的規模で、世代にまたが る外部不経済の処理を行うためには、市場を補完・補強するための手段として、政府ないしは何らかの国際機 関による計画的な対策が不可欠である。地球的規模での長期的な環境資源管理の理念と理論が求められる。

文献

[1] P. S. Dasgupta and G. M. Heal: "Economic Theory and Exhaustible Resources" (Cambridge University Press, 1979)

[2] W.Strobele: "Energy and Time in the Economic and Physical Sciences "(eds W.van Gool and J. J.C.Bruggink, NorthHolland, Amsterdam, 1985), pp.61-78

[3] J.A.Laurmann: "Carbon Dioxide, Current Views and Developments in Energy/Climate Research" (eds W.Bach et al, D.Reidel Publishing Company, Dordrecht/Boston/Lancaster, 1982), pp.415-460

[4] R.Kummel and W.Strassel: Ref.[2], pp.175-194 